\title{
Pérez Redondo, Rubén José (2017): El Tomelloso literario. Una profecía autocumplida. Ciudad Real: Diputación Provincial de Ciudad Real, 141 pp. ISBN: 978-84-7789-343-1.
}

Las relaciones de la literatura con la sociedad han sido un terreno fecundo de investigación para la sociología. Aunque, es necesario reconocer, discontinuo. La posible influencia de los valores o de la estructura social en la creación literaria o, a la inversa, de la novela, el teatro o, entre otros géneros, la poesía en los valores y la acción de los individuos es un tema recurrente en la sociología de la cultura. Es más, la famosa polémica en torno a la "determinación" de la cultura por la estructura social o de la estructura social por la cultura también estuvo presente en el estudio sociológico de la literatura.

El profesor Rubén J. Pérez Redondo retoma las preocupaciones clásicas de la sociología de la literatura aplicándolas a un caso particular: la localidad manchega de Tomelloso. El objeto de estudio es peculiar en cuanto a la producción literaria, ya que destaca tanto por la cantidad como por la calidad de sus escritores y poetas. Se llegó a denominar a la localidad, quizá un tanto hiperbólicamente, como la "Atenas de la Mancha". La localidad cuenta con autores de relevancia nacional como Francisco García Pavón, Eladio Cabañero, Félix Grande o Dionisio Cañas. Y de muchos otros que, sin tener el mismo impacto, dan muestra del vigor literario de la localidad. Entre ellos se puede citar a Francisco Martínez Ramírez "el Obrero de Tomelloso", Luis Quirós Arias, Juan Torres Grueso, Ignacio Castellanos González, Jesús Madrigal Olmedo, Faustino Rosado Castillo, José López Martínez, Ángel López Martínez, Pepe Carretero López, Manuel Moreno Díaz, Francisco Navarro Navarro, José Pozo Madrid, María José García Bolós o, entre otros, Miguel Ángel Bernao Burrieza. A estos literatos podríamos añadir el nombre del pintor Antonio López, quizá una de las figuras del mundo artístico más destacadas en la actualidad.

En principio esta localidad no tiene nada de peculiar: en la actualidad es un municipio de cerca de 37.000 habitantes dedicados tradicionalmente a tareas agrícolas, en especial al cultivo de la vid. Se adapta relativamente bien al término de "agrociudad", esto es, un núcleo urbano de pequeño tamaño enclavado en un entorno rural. La pregunta que el profesor Pérez Redondo trata de desentrañar, por tanto, versaría sobre esta peculiaridad. ¿Por qué existe esta tradición literaria en un municipio como el propuesto?

Tomelloso tuvo una práctica literaria popular, raras veces escrita, a finales del siglo XIX y comienzos del XX. Es la literatura de "Quinterías", que tenía una temática religiosos o relacionada con las prácticas de los oficios agrarios. Las elites locales también generaron cierta corriente literaria entre finales del siglo XIX y la Guerra Civil, que enmarcaba reclamaciones materiales como la llegada del ferrocarril a la localidad. Este sustrato, no obstante, tampoco era muy diferente del que podría ocurrir en otras pequeñas ciudades de provincias en la España de la época. Tras la Guerra Civil ocurrieron algunos hechos que azuzaron el espíritu literario de la localidad. La aparición de la revista Albores del espíritu -impulsada por el sacerdote Pedro Benítez García-; y, sobre todo, el surgimiento de la Fiesta de las Letras con sus premios literarios, fomentaron el amor por la literatura en Tomelloso. No obstante lo anterior, por sí mismos estos hechos no son tan excepcionales. ¿Qué es lo que hace decir a los tomelloseros que son una "posada de vid y cultura"?

El meollo de la cuestión no radica, según el estudio, en estos elementos previos, aunque los presupone. Son bastantes comunes en nuestra geografía. Según el autor, la literatura en Tomelloso se ha convertido en emblema identitario para sus habitantes. Los tomelloseros creen que su pueblo tiene un "don" literario y esto refuerza la inversión en la literatura, tanto a nivel personal como colectivo. Aquellos que tiene vocación se ven reforzados en la misma y las autoridades organizan eventos culturales para incentivar esas vocaciones. El fenómeno literario funciona, en consecuencia, como una profecía autocumplida. Pero dejemos hablar al profesor Pérez Redondo:

"Esto es justo lo que sucede en Tomelloso; sus gentes, en gran medida, han interiorizado como creencia la expectativa de que son un pueblo de artistas y escritores. Deducimos que en Tomelloso se ha propiciado todo un universo simbólico asentado en la Literatura (y la pintura) a partir de la creencia de una singularidad cultural que ha sido vertebrada con la creación de mitos y refrendada con instituciones y organismos que la han alimentado y sostenido en el tiempo. La mitología literaria tomellosera ha surgido de una mezcla entre situaciones reales, aunque agrandadas (la de la verdadera existencia de una afición por la literatura) y discursos de personalidades eminentes del panorama cultural, tanto local como de fuera, que dará fuerza al argumentario literario" (pp. 126-127).

De este modo, podríamos decir que la existencia de un fenómeno literario peculiar en Tomelloso combina aspectos sociales y culturales al mismo tiempo. Cierta infraestructura previa: una tradición literaria oral de carácter popular, alguna revista literaria en el erial cultural de la postguerra de la Guerra Civil y la instauración de unos premios literarios, junto a una construcción identitaria en torno a la literatura contribuyen a explicarlo. A ello habría que sumar, como nos informa el autor, la creación de redes de literatos en 
función de sus comunes orígenes una vez que se desplazaban a la "capital" para hacer carrera literaria.

Respecto a la edición, el libro se encuentra publicado en dentro de la colección de la Biblioteca de Autores Manchegos que edita la Diputación Provincial de Ciudad Real. La portada cuenta con un dibujo de José Luis Cabañas y el interior del volumen se encuentra ilustrado con un buen número de fotografías históricas y actuales de los actores e hitos de la historia literaria tomellosera. La obra viene precedida, además, de un prólogo del famoso poeta Dionisio Cañas, oriundo de Tomelloso. Se trata, en definitiva, de una cuidada edición que da lustre a un texto escrito de un modo conciso y accesible.

En definitiva, encontramos un trabajo de investigación notable, adecuadamente documentado y que dentro de los límites de la colección en la cual ha visto la luz (la Biblioteca de Autores Manchegos es una colección divulgativa dirigida a un público amplio) intenta analizar, con las herramientas de la sociología de la cultura y la literatura, una realidad peculiar. Creo que el profesor Pérez Redondo lo ha logrado.

María Gómez Escarda http://orcid.org/0000-0002-2785-7077 Universidad Nacional de Educación a Distancia Madrid, España mgomez@poli.uned.es

Recibida: 07-06-2018 Aceptada: 15-09-2018 